\title{
Peran Mediasi Komitmen Organisasi pada Pengaruh Beban Kerja terhadap Kinerja Karyawan
}

\author{
Indra Setiawan \\ Universitas Pelita Bangsa \\ Indra.setiawan@pelitabangsa.ac.id
}

\author{
Nur Aeni \\ Universitas Pelita Bangsa \\ Nur.aeni@pelitabangsa.ac.id
}

\begin{abstract}
The purpose of this study is to determine whether there is an effect of workload on employee performance mediated by organizational commitment. The object of research at PT KY Indonesia, Cikarang. The research was conducted using quantitative methods with SEM Smart PLS software as an analysis tool. The number of samples obtained by random sampling using the Slovin formula totaled 57 respondents. Data collection is done by using google forms in filling out online surveys. The data analysis method used is the R-square test, Bootstrapping, Path Coefficient, and Specific indirect effects. The results of this study indicate that workload affects employee performance, the workload has a positive and significant effect on organizational commitment, organizational commitment has a positive and significant impact on employee performance, organizational commitment can have a positive influence in mediating the relationship between workload and employee performance in PT KY Indonesia.
\end{abstract}

\section{Keywords Work load, organizational commitment, Employee performance}

\section{LATAR BELAKANG}

Tingkat persaingan dalam dunia bisnis pada kondisi saat ini semakin tinggi. Adanya area bisnis baru dan keberadaan teknologi atau strategi yang semakin maju yang dimiliki masingmasing perusahaan bertujuan untuk mengimbangi persaingan bisnis yang ada. Agar dapat bertahan dan berkembang dalam kondisi tersebut, perusahaan harus mampu mengembangkan sumber dayanya. Sumber daya perusahaan merupakan sumber daya penting untuk pembangunan berkelanjutan perusahaan. Mengingat sumber daya manusia merupakan aset utama perusahaan, maka sumber daya manusia tersebut harus dikelola dan dimanfaatkan secara seimbang dan manusiawi. Perusahaan membutuhkan sumber daya ini untuk mencapai tujuannya. Keberhasilan perusahaan dalam mengelola sumber daya manusia sangat menentukan keberhasilan tujuan perusahaan. Perusahaan akan selalu berupaya untuk meningkatkan kinerja karyawan demi tercapainya tujuan perusahaan. Kinerja terdiri dari serangkaian perilaku yang ditentukan oleh pengetahuan teknis seseorang yaitu pengetahuan khusus dalam bidang profesional, keterampilan dan kemampuan beradaptasi yaitu mengetahui proses pelaksanaan dan pelaksanaan sesuai dengan situasi, dan hubungan interpersonal (Pradhan \& Jena, 2017). 
Kinerja karyawan sangat mempengaruhi perkembangan perusahaan itu sendiri. Kinerja karyawan yang baik akan meningkatkan nilai keberhasilan dalam mendorong perkembangan perusahaan. Sebaliknya, kinerja karyawan yang buruk akan menghambat perkembangan perusahaan itu sendiri. Untuk mencapai kinerja yang baik, perusahaan harus memperhatikan beberapa aspek pekerjaan yang dilakukan oleh karyawan. Salah satunya mengenai tingkat kesulitan pekerjaan. Jika tingkat kesulitan pekerjaan tersebut sesuai dengan kemampuan karyawan, maka tingkat keberhasilan karyawan dalam menyelesaikan pekerjaan tersebut dapat berjalan dengan baik. Beban kerja tersebut meliputi tingkat kesulitan karyawan atau tingkat pekerjaan yang diberikan oleh karyawan tersebut. Beban kerja tersebut harus disesuaikan dengan kemampuan karyawan yang berperan penting bagi perusahaan dalam menyediakan beban kerja yang sesuai bagi karyawan. Di bawah tekanan dan beban kerja yang moderat, kinerja dapat ditingkatkan, karena dapat sepenuhnya merangsang energi karyawan untuk melakukan tugas secara efektif, tetapi mereka tidak dapat terlalu banyak mengalihkan fokus. Pada tingkat rendah, tingkat stres mungkin terlalu rendah untuk meningkatkan kinerja yang efektif, sedangkan pada tingkat tinggi, rangsangan stres mungkin terlalu tinggi untuk memberi manfaat pada kinerja yang efektif (Bruggen, 2015).

Dalam hal ini, jika beban kerja yang diberikan melebihi kemampuan karyawan, maka karyawan tersebut dapat membawa kinerja yang buruk bagi perusahaan. Ini akan menghambat realisasi tujuan perusahaan. Dengan demikian, beban kerja yang tepat akan memberikan kinerja yang baik bagi perusahaan dan mencapai tujuan perusahaan.

Berikut data target dan realisasi pengiriman produk assembly PT KY Indonesia yang diberikan oleh pelanggan PT. IEI Cikarang.

Tabel 1. Data Result Delivery PT KY Indonesia

\begin{tabular}{|l|l|l|l|l|l|l|l|l|l|l|l|}
\cline { 2 - 11 } \multicolumn{1}{c|}{} & Nov-19 & Des-19 & Jan-20 & Feb-20 & Mar-20 & Apr-20 & Mei-20 & Jun-20 & Jul-20 & Agu-20 & Sep-20 \\
\hline $\begin{array}{l}\text { Target } \\
\begin{array}{l}\text { Delivery } \\
\text { (PCS) }\end{array}\end{array}$ & 225.191 & 289.279 & 218.415 & 240.473 & 310.407 & 182.659 & 111.440 & 290.694 & 319.012 & 316.139 & 306.305 \\
\hline $\begin{array}{l}\text { Delivery } \\
\text { QTY } \\
\text { (PCS) }\end{array}$ & 365.074 & 316.258 & 277.153 & 278.114 & 302.300 & 255.535 & 118.954 & 293.194 & 386.746 & 420.104 & 220.979 \\
\hline
\end{tabular}

Sumber : WH Assembly Dept. PT Kiyokuni Indonesia

Dari data di atas terlihat bahwa tingkat permintaan pengiriman PT KY Indonesia setiap bulannya terus meningkat. Mulai November 2019, target pengirimannya 225.191 unit / unit, dan kini meningkat menjadi 365.074 unit / unit.Pada bulan Desember 2019, Januari 2020, Februari 2020, April 2020, Mei 2020, Juni 2020, Juli 2020 dan Agustus 2020, target pengiriman hingga pengiriman aktual meningkat. Namun berbeda dengan Maret 2020 dan September 2020 yang kebetulan satu bulan dari target awal pengiriman hingga pengiriman sebenarnya. Pasalnya, wabah Covid-19 merebak di bulan itu, dan karena terhentinya jalur produksi dari awal September hingga pertengahan September, permintaan pengiriman PT IEI menurun.

Berdasarkan uraian di atas terlihat bahwa permintaan produksi meningkat dari target awal hingga pengiriman aktual, yang meningkatkan beban kerja karyawan, karena sebagian karyawan terpaksa bekerja lembur, dan semua karyawan harus memenuhi target. Oleh karena itu, karyawan harus lebih berupaya untuk memenuhi permintaan pelanggan akan pengiriman. Untuk mencegah penurunan kinerja karyawan karena beban kerja yang meningkat, maka organisasi akan berusaha sebaik mungkin untuk menjaga kinerja pegawai yang baik. Artinya 
dalam suatu organisasi yang dipercaya oleh karyawan dapat memberikan perlindungan bagi karyawan, menjamin kesejahteraan karyawan, dan memberikan fasilitas yang baik kepada karyawan. Dalam hal ini perusahaan akan berupaya untuk memungkinkan karyawan memiliki komitmen yang tinggi terhadap organisasi dan dapat bergabung dengan organisasi dengan percaya diri. Menurut Chanpoom \& Intrawong (2019). komitmen organisasi penting untuk menunjukkan kemauan untuk berbuat baik bagi organisasi, kepentingan organisasi dan karyawannya. Kepercayaan karyawan untuk terus menjadi anggota organisasi. Komitmen organisasi akan membantu menurunkan laju pergantian pekerjaan, dan juga merepresentasikan potensi organisasi untuk mengatasi berbagai masalah. Komitmen karyawan terhadap organisasi, Karyawan akan berusaha untuk bertahan dalam organisasi dan memberikan kinerja yang baik untuk organisasi. Komitmen karyawan terhadap organisasi dapat memungkinkan karyawan memberikan kinerja yang baik untuk mencapai tujuan organisasi atau perusahaan.

\section{LANDASAN TEORI \\ Kinerja}

Kinerja merupakan hasil akhir dari suatu proses yang dilakukan oleh karyawan atau pegawai dimana kinerja ini akan menjadi nilai dimata manajemen apakah karyawan bersangkutan berprestasi atau tidak (Pinatih \& Gorda, 2017). Menurut Trang (2018) kinerja karyawan dapat disimpulkan sebagai otuput atau hasil kerja karyawan sesuai dengan tugas dan tanggung jawabnya untuk mencapai tujuan organisasi. Namun Irawati \& Carollina (2017) juga berpendapat bahwa kinerja karyawan merupakan suatu hasil kerja yang dihasilkan oleh seorang pegawai diartikan untuk mencapai tujuan yang diharapkan. Dari beberapa definisi diatas, penulis menyimpulkan bahwa kinerja adalah hasil kerja pada suatu organisasi atau perusahaan dalam melaksanakan tugas, target atau sasaran perusahaan yang telah dikerjakan seorang pegawai berdasarkan tanggung jawabnya guna mencapai tujuan perusahaan.

\section{Beban Kerja}

Beban kerja adalah suatu hal yang berkaitan dengan kondisi fisik dan psikis atau mental seorang pegawai yang dipengaruhi oleh faktor tanggung jawab yang timbul atas pekerjaannya dalam suatu organisasi. (Pinatih \& Gorda, 2017). Menurut Muhammad et al., (2016) Beban kerja merupakan tanggung jawab yang diberikan atasan dan harus diselesaikan sesuai waktu yang ditentukan demi tercapainya tujuan. Sedangkan menurut Widodo Hariyono ,Dyah Suryani \& Yanuk Wulandari (2009) Beban kerja adalah lama seseorang melakukan aktivitas pekerjaan sesuai dengan kemampuan dan kapasitas kerja yang bersangkutan tanpa menunjukkan tanda kelelahan. Berdasarkan beberapa definisi di atas penulis menyimpulkan bahwa beban kerja adalah suatu bentuk tanggung jawab yang diberikan karyawan kepada perusahaan tempat mereka bekerja sesuai dengan target yang telah ditetapkan guna mencapai tujuan perusahaan.

\section{Komitmen Organisasi}

Menurut Sohail (2011) Komitmen organisasi dibagi menjadi dua bagian besar berdasarkan sudut pandang; yaitu sikap dan perilaku. Perasaan dan pemikiran karyawan tentang organisasi mengacu pada komitmen sikap sedangkan pola individu yang ditetapkan ke dalam organisasi mengacu pada komitmen perilaku. Menurut Muis et al., (2018) komitmen organisasi merupakan proses pada individu (pegawai) dalam mengidentifikasikan dirinya dengan nilai- 
nilai, aturan-aturan dan tujuan organisasi. Komitmen organisasi pada sebuah perusahaan merupakan salah satu jaminan untuk menjaga kelangsungan perusahaan tersebut. Komitmen adalah semacam kesepakatan antara individu-individu di dalamnya yang bersifat mengikat dan mengarah pada keseluruhan (Sidharta \& Meily Margaretha, 2011). Berdasarkan definisi diatas, penulis menyimpulkan bahwa komitmen organisasi adalah suatu sikap atau perilaku yang dilakukan oleh pegawai sesuai dengan aturan atau norma-norma yang berlaku agar dapat menjadi agian dalam organisasi tersebut.

\section{Pengembangan Hipotesis}

Hubungan beban kerja terhadap kinerja karyawan

Beban kerja merupakan bentuk tuntutan tugas yang diberikan perusahaan terhadap karyawan. Hubungan beban kerja terhadap kinerja karyawan berpengaruh positif dan signifikan . Artinya semakin tinggi beban kerja karyawan maka akan semakin melatih kemampuan dan pengalaman karyawan sehingga dapat menghasilkan kinerja yang semakin baik (Pinatih \& Gorda, 2017). Berdasarkan hasil dari penelitian terdahulu, maka dapat diajukan hipotesis sebagai berikut:

H1 : Beban kerja berpengaruh terhadap kinerja karyawan.

\section{Hubungan beban kerja terhadap komitmen organisasi}

Beban dapat diartikan sebagai suatu aktivitas pekerjaan yang menggunakan semua organ tubuh untuk memenuhi tuntutan pekerjaan yang dihadapi baik secara fisik maupun mental. Jika terjadi beban kerja yang berlebihan tentu akan mempengaruhi komitmen organisasional.Hal ini diperkuat oleh peelitian yang dilakukan Wibowo, (2006) mengatakan bahwa beban kerja berpengaruh signifikan terhadap komitmen organisasional. Robbins, (2006) mengatakan bahwa beban kerja merupakan faktor yang terkait pekerjaan seseorang yang dapat memberi tekanan pada orang apabila tuntutan tugas kecepatannya dirasakan berlebihan dapat meningkatkan kecemasan dan menurunnya komitmen. Berdasarkan hasil dari penelitian terdahulu, maka dapat diajukan hipotesis sebagai berikut:

$\mathrm{H} 2$ : Beban kerja berpengaruh terhadap kinerja karyawan.

\section{Pengaruh komitmen organisasi terhadap kinerja karyawan}

Komitmen organisasi mengacu pada kepercayaan karyawan terhadap perusahaan. Rasa percaya dan ingin tetap berada dalam perusahaan menjadikan karyawan memberikan kinerja yang baik kepada perusahaan. Hubungan komitmen organisasi dengan kinerja karyawan yang positif dan signfikan dapat diartikan bahwa apabila komitmen organisasional meningkat, maka kinerja karyawan juga akan mengalami peningkatan (Sri Wahyudi \& Sudibya, 2016). Berdasarkan hasil dari penelitian terdahulu, maka dapat diajukan hipotesis sebagai berikut: H3 : Beban kerja berpengaruh terhadap kinerja karyawan.

Pengaruh beban kerja terhadap kinerja karyawan yang di mediasi komitmen organisasi Pada tingkat tertentu peningkatan beban kerja pegawai namun masih dalam kapasitas pegawai tersebut diindikasikan dapat meningkatkan output kerjanya. Sebaliknya apabila beban kerja pegawai yang melampaui kemampuan dan kapasitas pegawai akan menyebabkan penurunan output kerja pegawai tersebut. Pegawai dengan komitmen yang tinggi cenderung merasa senang dalam bekerja karena mereka harus mewujudkan apa yang telah menjadi keyakinan mereka dalam organisasi. Organisasi akan sangat diuntungkan karena kinerja mereka cenderung stabil atau bahkan meningkat. Sentot Iskandar dan Gredi Granada Sembada (2012) 
menyatakan bahwa Beban kerja memberikan pengaruh yang signifikan terhadap kinerja pegawai. Berdasarkan hasil dari penelitian terdahulu, maka dapat diajukan hipotesis sebagai berikut:

H4 : Beban kerja berpengaruh terhadap kinerja karyawan yang di mediasi komitmen organisasi

\section{Desain Penelitian}

Berdasarkan kajian teori dan review hasil penelitian terdahulu yang telah dipaparkan, dapat disimpulkan bahwa peningkatan kinerja karyawan secara umum dipengaruhi oleh berbagai faktor. Penelitian ini terfokus pada beban kerja, komitmen organisasi dan kinerja. Berdasarkan uraian tersebut, maka dapat dirumuskan desain enelitian sebagaimana tertera pada gambar 1

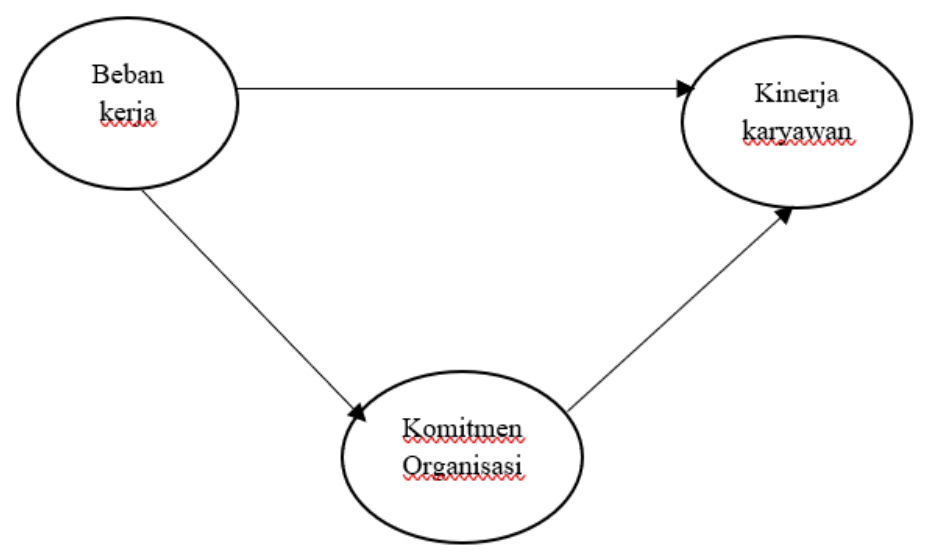

Gambar 1. Design Penelitian

\section{METODE PENELITIAN}

Jenis Penelitian yang dilakukan adalah penelitian dengan pendekatan kuantitatif. Populasi pada penelitian ini adalah seluruh karyawan departmen asembly PT KY Indonesia dengan jumlah 135 karyawan. Jumlah sampel ditentukan menggunakan rumus slovin dengan margin eror $10 \%$ yaitu berjumlah 57 metode pengumpulan data yang dilakukan adalah dengan cara membagikan daftar pertanyaan kepada responden agar responden tersebut memberikan jawabannya. Metode analisis data menggunakan software SmartPLS versi 3.0. Metode analisis data yang digunakan adalah uji R- square, Bootstrapping,Path Coefficient, dan Specific indirect effects dengan software Smart PLS. Pengujian model struktural dilihat dari nilai $R$-Square. Selanjutnya evaluasi model dilakukan dengan melihat nilai signifikan untuk mengetahui antar variable melalui proses bootstrapping untuk precision dan estimasi PLS. Bootstrapping adalah teknik statiska yang berada dibawah judul resampling yang lebih luas. Teknik ini melibatkan prosedur yang relative sederhana namun berkali-kali diulang sehingga sangat bergantung pada perhitungan software Smart PLS.

\section{HASIL PEMBAHASAN}

Pengujian Model Struktular (Inner Model) 
Pengujian model struktural (Inner model) dapat dilakukan dengan tiga metode yaitu $R$-square, path coefficients dan specific indirect effects.

\section{R-Square}

Tabel 2. Hasil Uji R-Square

\begin{tabular}{cc}
\hline Variabel & R Square \\
\hline Kinerja Karyawan (KK) & 0.617 \\
\hline Komitmen Organisasi (KO) & 0.479 \\
\hline
\end{tabular}

Sumber : Output SmartPLS 3,0 (2020)

Berdasarkan Tabel 2. dapat dilihat bahwa Model Beban kerja terhadap kinerja karyawan memberikan nilai $R$-square sebesar 0,617 dapat diartikan bahwa variabel Kinerja karyawan dapat dijelaskan dengan variabel konstruk Beban kerja sebesar 61,7\% , sedangkan 38,3\% dijelaskan oleh variabel lain diluar penelitian ini. Pengaruh lainnya terdapat dalam model komitmen organisasi dengan nilai $R$-square sebesar 0,082 dapat di artikan bahwa variabel komitmen organisasi dapat dijelaskan dengan variabel kontruk Beban kerja sebesar 8,2\% sedangkan 91,8\% dijelaskan oleh variabel lain diluar penelitian ini.

\section{Path Coefficient}

Pengujian ini dilakukan untuk mengetahui pengaruh langsung antara variabel eksogen dengan endogen dengan melakukan bootstrapping. Diketahui melalui nilai T-Statistic. Dimana nilai T-statistic yang digunakan adalah 1.96 .

Model Test:

- $\quad$ Jika nilai T-statistic > 1,96 maka Hipotesis diterima

- $\quad$ Jika nilai $T$-statistic < 1,96 maka Hipotesis ditolak

Berikut ini adalah hasil uji path coefficient dalam SmartPLS 3,0 oleh peneliti :

Tabel 3. Path coeffiecient

\begin{tabular}{llllll}
\hline Variabel & $\begin{array}{l}\text { Original } \\
\text { sample } \\
(\mathbf{O})\end{array}$ & $\begin{array}{l}\text { Sample } \\
\text { Mean } \\
(\mathbf{M})\end{array}$ & $\begin{array}{l}\text { Standard } \\
\text { Deviation } \\
(\mathbf{S T D E V})\end{array}$ & $\begin{array}{l}\text { T Statistics } \\
(|\mathbf{O} / \mathbf{S T D E V}|)\end{array}$ & P Values \\
\hline $\begin{array}{l}\text { Beban Kerja -> Kinerja } \\
\text { Karyawan }\end{array}$ & 0,243 & 0,232 & 0,092 & 2,656 & 0,008 \\
\hline $\begin{array}{l}\text { Beban Kerja -> Komitmen } \\
\text { Organisasi }\end{array}$ & 0,692 & 0,705 & 0,076 & 9,134 & 0,000 \\
\hline $\begin{array}{l}\text { Komitmen Organisasi } \\
\text {-> Kinerja Karyawan }\end{array}$ & 0,598 & 0,612 & 0,091 & 6,538 & 0,000 \\
\hline
\end{tabular}

Sumber : Output SmartPLS 3,0 (2020)

Berdasarkan tabel 3. dapat dilihat bahwa pengaruh langsung antara variabel beban kerja dengan variabel kinerja karyawan memberikan hasil uji t-statistic sebesar 4,132 > 1,96 (nilai $t$-statistic yang digunakan), artinya hipotesis diterima. Pengaruh langsung antara variabel beban kerja dengan variabel komitmen organisasi memberikan hasil uji $t$-statistic sebesar 2,939 $>$ 1,96 (nilai $t$-statistic yang digunakan), artinya hipotesis diterima.Pengaruh langsung antara variabel komitmen organisasi dengan variabel kinerja karyawan memberikan hasil uji $t$ statistic sebesar 10,919>1,96 (nilai $t$-statistic yang digunakan), artinya hipotesis diterima. 


\section{Specific Indirect Effect}

Pengujian dilakukan untuk mengetahui pengaruh tidak langsung antara variabel eksogen dengan endogen dengan melakukan bootstrapping. Diketahui melalui nilai T-Statistic. Dimana nilai $t$-statistic yang digunakan adalah 1.96.

Model Test:

- Jika nilai T-statistic > 1,96 maka Hipotesis diterima

- Jika nilai T-statistic < 1,96 maka Hipotesis ditolak

Berikut ini adalah hasil uji specific indirect effect dalam SmartPLS 3,0 oleh peneliti :

Tabel 4. Specific Indirect Effects

\begin{tabular}{llllll}
\hline Variabel & $\begin{array}{l}\text { Original } \\
\text { sample } \\
(\mathbf{O})\end{array}$ & $\begin{array}{l}\text { Sample } \\
\text { Mean } \\
(\mathbf{M})\end{array}$ & $\begin{array}{l}\text { Standard } \\
\text { Deviation } \\
(\text { STDEV) }\end{array}$ & $\begin{array}{l}\text { T Statistics } \\
(\mid \mathbf{O} / \text { STDEV|) }\end{array}$ & P Values \\
\hline $\begin{array}{l}\text { Beban Kerja }>\text { Komitmen } \\
\begin{array}{l}\text { Organisasi } \rightarrow \text { Kinerja } \\
\text { Karyawan }\end{array}\end{array}$ & 0,413 & 0,430 & 0,075 & 5,534 & 0,000 \\
\hline
\end{tabular}

Sumber : Output SmartPLS 3,0 (2020)

Berdasarkan tabel 4. dapat dilihat bahwa pengaruh tidak langsung antara variabel beban kerja , komitmen organisasi dan kinerja karyawan memberikan hasil $t$-statistic sebesar 3,232 > 1,96 (nilai $t$-statistic yang digunakan), artinya dalam uji tersebut hipotesis diterima. Berikut ini adalah gambar hasil uji bootstrapping dalam SmartPLS 3,0 yang dilakukan oleh peneliti :

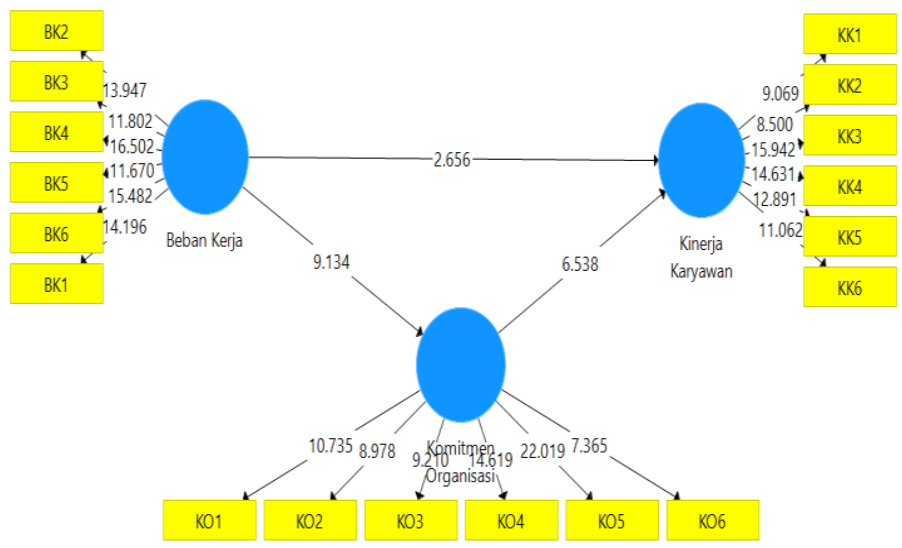

Sumber : Output SmartPLS 3,0 (2020)

Gambar 2. Output Bootstrapping

\section{Pembahasan}

Berdasarkan hasil data analisis SmartPLS 3,0 yang dilakukan oleh peneliti, dapat dinyatakan bahwa variabel beban kerja berpengaruh positif dan signifikan terhadap variabel kinerja karyawan. Artinya semakin tinggi variabel beban kerja maka akan semakin tinggi pula kinerja karyawan. Jadi, pernyataan mengenai $\mathrm{H} 1$ tersebut dapat di terima. Penelitian ini sejalan dengan penelitian yang dilakukan oleh (Muhammad et al., 2016), bahwa beban kerja berpengaruh terhadap kinerja karyawan. Namun hal tersebut bertentangan dengan penelitian 
yang dilakukan oleh (Ahmad et al., 2019) yang menunjukkan bahwa beban kerja berpengaruh positif dan tidak signifikan terhadap kinerja pegawai. Artinya beban kerja tidak berpengaruh terhadap kinerja pegawai. Hasil penelitian ini menunjukan bahwa semakin tingginya beban kerja yang diberikan perusahaan terhadap karyawannya akan semakin tinggi pula usaha yang dilakukan karyawan untuk mencapai kinerjanya.

Berdasarkan hasil data analisis SmartPLS 3,0 yang dilakukan oleh peneliti, dapat dinyatakan bahwa variabel beban kerja berpengaruh positif dan signifikan terhadap variabel komitmen organisasi. Artinya semakin tinggi variabel beban kerja maka akan semakin tinggi pula komitmen organisasi. Jadi, pernyataan mengenai $\mathrm{H} 2$ tersebut dapat di terima. Penelitian ini sejalan dengan hasil penelitian yang dilakukan oleh (Tiala et al., 2019) bahwa beban kerja berpengaruh positif signifikan terhadap komitmen organisasi. Hubungan ini menunjukkan bahwa jika beban kerja tinggi maka komitmen organisasi akan tinggi. Hasil penelitian ini menunjukan bahwa adanya beban kerja yang tinggi dapat diatasi dengan adanya komitmen karyawan terhadap organisasi/perusahaan yang tinggi pula.

Berdasarkan hasil data analisis SmartPLS 3,0 , dapat dinyatakan bahwa variabel komitmen organisasi berpengaruh positif dan signifikan terhadap variabel kinerja karyawan. Artinya semakin tinggi variabel komitmen organisasi maka akan semakin tinggi pula kinerja karyawan. Jadi, pernyataan mengenai $\mathrm{H} 3$ tersebut dapat di terima. Penelitian ini sejalan dengan penelitian yang dilakukan oleh (Muis et al., 2018). Hasil penelitian menunjukkan bahwa komitmen organisasi berpengaruh positif dan penting terhadap kinerja karyawan. Dalam hal ini komitmen organisasi berdampak baik terhadap kinerja karyawan perusahaan. Hasil penelitian ini menunjukan bahwa adanya komitmen karyawan terhadap organisasi/perusahaan menjadikan karyawan lebih berusaha untuk menjamin kemajuan organisasi/perusahaan yaitu dengan memberikan kinerja yang baik kepada organisasi/perusahaan.

Berdasarkan hasil data analisis SmartPLS 3,0 diatas , dapat dinyatakan bahwa variabel beban kerja berpengaruh positif dan signifikan terhadap variabel kinerja karyawan melalui mediasi komitmen organisasi. Artinya semakin tinggi variabel beban kerja dan komitmen organisasi maka akan semakin tinggi pula kinerja karyawan. Jadi, pernyataan mengenai H4 tersebut dapat di terima. Penelitian ini sejalan dengan penelitian yang dilakukan oleh (Iskandar \& Sembada, 2012) yang menyatakan bahwa Beban kerja memberikan pengaruh yang signifikan terhadap kinerja pegawai. Artinya beban kerja yang dirasakan dapat menentukan perilaku kerja atau kinerja. Penelitian mengenai komitmen organisasi juga sejalan dengan penelitian yang dilakukan oleh (Suwardi \& Utomo, 2011) yang memberikan hasil bahwa komitmen organisasi berpengaruh positif dan signifikan terhadap kinerja karyawan. Hasil penelitian ini menunjukan bahwa adanya komitmen organisasi sebagai variabel mediasi menjadikan karyawan lebih mengedepankan kepentingan organisasi agar mampu tetap bertahan dalam organisasi/perusahaan tersebut. Jadi adanya beban kerja yang tinggi akan teralihkan dengan adanya komitmen karyawan terhadap organisasi/perusahaan dan karyawan akan memberikan kinerja yang baik untuk kemajuan organisasi/perusahaan tersebut.

\section{KESIMPULAN}

Berdasarkan hasil pengujian, pengolahan dan analisis data yang telah dilakukan oleh peneliti mengenai pengaruh beban kerja terhadap kinerja karyawan , pengaruh beban kerja terhadap komitmen organisasi, pengaruh komitmen organisasi terhadap kinerja karyawan dan pengaruh beban kerja terhadap kinerja karyawan yang dimediasi oleh komitmen organisasi. Pengujian hipotesis menggunakan program analisis data SmartPLS 3,0, setelah dilakukan analisis maka 
dapat ditarik kesimpulan bahwa beban kerja memiliki pengaruh positif dan signifikan terhadap kinerja karyawan PT Kiyokuni Indonesia. Sehingga dapat disimpulkan bahwa semakin tinggi beban kerja yang diberikan perusahaan terhadap karyawannya akan semakin tinggi pula usaha yang dilakukan karyawan untuk mencapai kinerjanya. Beban kerja memiliki pengaruh positif dan signifikan terhadap komitmen organisasi PT Kiyokuni Indonesia. Sehingga dapat disimpulkan bahwa beban kerja yang tinggi dapat diatasi dengan adanya komitmen karyawan terhadap organisasi/perusahaan yang tinggi pula. Komitmen organisasi memiliki pengaruh positif dan signifikan terhadap kinerja karyawan PT Kiyokuni Indonesia. Sehingga dapat disimpulkan bahwa adanya komitmen karyawan terhadap organisasi/perusahaan menjadikan karyawan lebih berusaha untuk menjamin kemajuan organisasi/perusahaan yaitu dengan memberikan kinerja yang baik kepada organisasi/perusahaan. Beban kerja berpengaruh positif dan signifikan terhadap variabel kinerja karyawan melalui mediasi komitmen organisasi. Sehingga dapat disimpulkan bahwa adanya komitmen organisasi sebagai variabel mediasi menjadikan karyawan lebih mengedepankan kepentingan organisasi agar mampu tetap bertahan dalam organisasi/perusahaan tersebut. Jadi adanya beban kerja yang tinggi akan teralihkan dengan adanya komitmen karyawan terhadap organisasi/perusahaan dan karyawan akan memberikan kinerja yang baik untuk kemajuan organisasi/perusahaan tersebut.

\section{DAFTAR PUSTAKA}

Ahmad, Y., Tewal, B., Taroreh, R. N., Ekonomi, F., Manajemen, J., \& Ratulangi, U. S. (2019). Pengaruh Stres Kerja, Beban Kerja, Dan Lingkungan Kerja Terhadap Kinerja Karyawan Pada Pt. Fif Group Manado. Jurnal EMBA: Jurnal Riset Ekonomi, Manajemen, Bisnis Dan Akuntansi, 7(3), 2811-2820. https://doi.org/10.35794/emba.v7i3.23747

Bruggen, A. (2015). An empirical investigation of the relationship between workload and performance. Management Decision, 53(10), 2377-2389. https://doi.org/10.1108/MD-02-2015-0063

Chanpoom, N., \& Intrawong, W. (2019). The Influence of Strategic Leadership and Organizational climate on Organizational Commitment of Savings Cooperative Employees, Thailand. ... Conference in Vienna ..., 307-314.

Dyah Suryani, Yanuk Wulandari, W. H. (2009). Perawat Di Rumah Sakit Islam Yogyakarta Pdhi. 3, 162-232.

Irawati, R., \& Carollina, D. A. (2017). Analisis Pengaruh Beban Kerja Terhadap Kinerja Karyawan Operator Pada Pt Giken Precision Indonesia. Inovbiz: Jurnal Inovasi Bisnis, 5(1), 51. https://doi.org/10.35314/inovbiz.v5i1.171

Iskandar, S., \& Sembada, G. G. (2012). Jurnal Ekonomi, Bisnis dan Entrepreneurship. Jurnal Ekonomi, Bisnis \& Entrepreneurship, 6(1), 26-38.

M. Suleman Sabir, Adil Sohail, M. A. K. I. (2011). Impact of Leadership Style on Organization Commitment: In A Mediating Role of Employee Values. 11(2), 10-14. https://doi.org/10.16194/j.cnki.31-1059/g4.2011.07.016

Muhammad, S. R., Adolfina, \& Lumintang, G. (2016). Pengaruh Lingkungan Kerja, Kompensasi Dan Beban Kerja Terhadap Kinerja Karyawan Pada Dinas Pendapatan Daerah Kota Manado the Influence of Work Environment, Compensation and Workload on the Performance of Employees in Dipenda Manado. Jurnal EMBA, 45(1), 45-055. 
Muis, M. R., Jufrizen, J., \& Fahmi, M. (2018). Pengaruh Budaya Organisasi Dan Komitmen Organisasi Terhadap Kinerja Karyawan. Jesya (Jurnal Ekonomi \& Ekonomi Syariah), 1(1), 9-25. https://doi.org/10.36778/jesya.v1i1.7

Pinatih, I. G. B. A., \& Gorda, A. A. N. E. S. (2017). Gaya kepemimpinan, beban kerja, stres kerja, teknologi informasi, dan kinerja karyawan. Jurnal Ilmiah Manajemen \& Bisnis, 2(2), 298-310.

Pradhan, R. K., \& Jena, L. K. (2017). Employee Performance at Workplace: Conceptual Model and Empirical Validation. Business Perspectives and Research, 5(1), 69-85. https://doi.org/10.1177/2278533716671630

Sidharta, N., \& Meily Margaretha. (2011). Dampak Komitmen Organisasi Dan Kepuasan Kerja Terhadap Turnover Intention: Studi Empiris Pada Karyawan Bagian Operator Di Salah Satu Perusahaan Garment. Jurnal Manajemen, 10(2), 129-142.

Sri Wahyudi, N., \& Sudibya, I. (2016). Pengaruh Kepuasan Kerja Dan Komitmen Organisasional Pada Kinerja Karyawan Di Natya Hotel, Kuta Bali. None, 5(2), 250270.

Suwardi, S., \& Utomo, J. (2011). Pengaruh Motivasi Kerja, Kepuasan Kerja, Dan Komitmen Organisasional Terhadap Kinerja Pegawai (Studi Pada Pegawai Setda Kabupaten Pati). Jurnal Analisis Manajemen, 5(1), 75-86.

Tiala, F., Ratnawati, \& Rokhman, M. T. N. (2019). JURNAL Ekonomi \& Bisnis Terapan. 15, 9-20.

Trang, D. S. (2018). Gaya Kepemimpinan Dan Budaya Organisasi Terhadap Kinerja Karyawan Studi pada Perwakilan BPKP Provinsi Sulawesi Utara. Jurnal EMBA. 